a large tract from which the Africans have been displaced and which to them seems reserved for animals and for American and European tourists ?

If the National Park is preserved from fire and from grazing, the grass may soon be too long for the antelopes, which will go to the grazed land outside the reserve and fall a ready prey to poachers. Despite the lack of present knowledge, there must be an attempt to secure a balance of grazing which will suit both domestic stock and wild animals. The Masai are a proud and a conservative people; but they love their cattle and, if it were shown that measures were designed to maintain their herds in their present numbers, in their present homelands, I think they would co-operate.

1 Pearsall, W. H., Oryx, 4, 73 (1957).

${ }^{2}$ Thomas, A. S., J. Ecol., 31, 149 (1943).

${ }^{3}$ Howarth, D., Sunday Times (Feb. 28, 1960).

\title{
THE WATHEROO MAGNETIC OBSERVATORY, MELBOURNE
}

$\mathrm{W}$ ATHEROO Magnetic Observatory was established in 1919 by the Carnegie Institution of Washington, at a site about 110 miles north of Perth, Western Australia, and about 50 miles from the coast. Since that date the Observatory has carried out a programme of observations in terrestrial magnetism and electricity and ionospheric research. In 1947 , the Observatory was transferred by gift to the Australian Commonwealth Government, and the Commonwealth Bureau of Mineral Resources, Geology and Geophysics has operated and maintained the Observatory since then.

In recent years there has been great difficulty in maintaining Watheroo Observatory as a residential establishment : so much so that consideration had to be given to moving the Observatory to suitable sites near Perth, where it would be possible to continue observations, and at the same time avoid the expense and staffing difficulties associated with the maintenance of a residential establishment in a remote locality. It was also believed that work of the Observatory would benefit from bringing the staff in closer contact with scientific workers at the University and other establishments in Perth.

In 1955, a site was selected in the Gnangara Pine Plantation, north of Perth, for magnetic observations, and another in the vicinity of Mundaring Weir, 20 miles east of Perth, in the Darling Ranges, for ionospheric and seismological observations. A site for an office and laboratory was selected in Mundaring township. When selecting observatory sites, the Bureau sought and was guided by the advice of many local and overseas scientific authorities.
The magnetic station was completed at Gnangara late in 1956, and observations and recordings began at that station in parallel with those at the Watheroo Observatory in July 1957. Both stations were operat. ing throughout the International Geophysical Year.

The buildings at Mundaring necessary for the transfer of ionospheric observations from Watheroo have now been completed. A new ionospheric recorder has been purchased and will be installed soon. Magnetic observations and recordings ceased at Watheroo on January 31,1959 , and on March 18 . 1959 , the other observatory activities were transferred to Mundaring. Seismological recording began at Mundaring in August 1959, using a three-component Benioff seismograph, with both long- and short. period galvanometers.

The new organization is known as Mundaring Geophysical Observatory, with headquarters in Mundaring township. The magnetic and ionospheric data are distributed on the same basis as for Watheroo, and seismological bulletins are issued on the same basis as for other stations operated by the Bureau.

For the particular scientific observations under. taken, the transfer from Watheroo to Mundaring will have no significant influence on the results. The move of about 100 miles is not important on the global scale. It is believed that, although Perth Observatory has operated seismographs for many years, the new Observatory will fill a real need for a high-sensitivity seismograph in this area.

Further information concerning the new establish. ment should be addressed to the Observer-in-Charge, Mundaring Geophysical Observatory, Mundaring, Western Australia.

\section{THE LE PLAY SOCIETY}

$F^{o}$ OUNDED in 1930 to encourage international studies along the lines advocated in the middle of last century by the French sociologist Frederic Le Play, the Le Play Society, under the direction of Miss Margaret Tatton, has for thirty years organized an annual 3-day conference and study visits to the less-familiar regions of Europe and North Africa. The formula for the overseas work was for a group with varied backgrounds to spend a few days getting the general 'flavour' of a country and then to settle down in a village to make an intensive study of the community and its environment. In the evenings geologist, botanist, agriculturist, geographer, sociologist, doctor, teacher would meet to pool their findings and, under expert visiting and local guidance, compare notes to build up a remarkably complete picture. About a dozen such studies reached a wider audience through publication as monographs.

On April 9-12, 1960, the Society met for the last time at Wadham College, Oxford, and Sir John Russell delivered his twenty-third annual address as president. Rather than face a slow decline, the Society decided to terminate its work in a blaze of glory - the final conference dealt with "Present Problems in World Affairs", with contributions from many angles by Prof. L. F. Rushbrook-Williams (India and Pakistan), Prof. A. L. Goodhart (International Law), Sir Reader Bullard (Middle East), Prof. L. Dudley Stamp (Food and Population), Dr. F. M. Brewernow mayor of Oxford (Science and the Ordinary Man), Mr. William E. Abraham of All Souls (African Independence), Prof. E. M. Hugh-Jones (America : 
The Influence of Affluence), Mr. E. Paget (West Indies), and Mr. N. H. Leyland (Economic Problems). Old friends who assisted in this final conference included Prof. H. J. Fleure, who presented to the president a handsomely bound volume including typescripts of his series of annual addresses, Sir Richard Livingstone, who took the chair at the presidential address, Prof. Kenneth Mason and more than a hundred members, who paid tribute in the form of a presentation to mark the devoted work of Miss Tatton.

The main reason for the decision to wind up the Society is a tragic commentary on the post-war world. While international tourism is being en- couraged, study groups which moved so freely and were accorded unstinted help everywhere in the inter-war years are now faced with official frustration and danger of arrest as spies if they attempt to see anything not on the accepted tourist routes. In addition, increasing costs have placed such journeys beyond the resources of younger people who, if they can get grants, are required to attend meetings in their own specialisms. Few seem to have leisure for the quiet exchange of views with workers in other fields. Le Play methods in social and regional survey have, however, become basic requirements in physical and social planning all over the world.

L. Dudley Stamp

\section{THE LACK OF THINKING IN EXAMINATIONS}

$I_{s}^{N}$ marking examination seripts, Dr. Margaret Sutherland, lecturer in education at the Queen's University, Belfast, has noticed that many students do not deal with the topic set (The Universities Review, 32, No. 7 ; February 1960). This occurs mainly in subjects which require a basic knowledge (of facts, or of a book, theory, or other works) and some more or less intelligent discussion of some aspect of this basic knowledge. The examiner has attempted to set a question which will differ from those set in previous papers and yet allow the students to display knowledge, select relevant data and comment reasonably thereon. To this, many students pour forth a statement of basic knowledge which is mostly without relevance to the question set.

Some examiners would classify this behaviour as 'examination technique' or conscious bluffing on the part of the students who, knowing that they are unlikely to pass, have memorized answers on strictly limited topics and are going to use them no matter what the question. But not all erring students can be credited with this conscious cunning, for some irrelevant answers display consciontious and thorough preparation.

Occasionally the explanation lies in the examiner's technique; the question may have been badly worded, the interpretation which seemed obvious to the examiner was not obvious to other readers ; thus seemingly irrelevant answers may prove relevant, if the question is re-interpreted.

In other cases the weakness seems to be in the student's reading ability. The student must be technically able to read the question; but the sense of the sentence is not grasped. One word only, or part of the sentence only, dominates the rest and evokes the associations to this one element. This is an example of the so-called global thinking supposedly characteristic of early childhood, where a general concept is present or brought to mind, but finer discriminations cannot be made, and analysis, perception of detail and component parts do not occur. This leads to regression to an earlier stage of behaviour, possibly caused, like other regressions, by a stressful situation. Yet surely the concepts in question have been analysed during preparation for the examination? Surely, too, the student has been trained to attend to the different parts of meaning conveyed by whole sentences?
Does the error occur in grasping the meaning of the question or in attempting to respond to it? If it is the latter, the behaviour may be explained as regression to another primitive type of mental activity, to rote-memory in which the information sought ean be reproduced only imbedded in the impressions originally accompanying it. It is difficult to believe that, having reproduced all the data, the student still cannot select from this reproduction all that is relevant.

Yet this the student seems unable to do. It is precisely selection and discussion that are avoided. It seems increasingly probable that this avoidance may be due not to ignorance of what is wanted, not to bluff or sophisticated examination technique, not to failure in reading ability, but to emotional factors of anxiety and fear. The student approaches the examination with the feeling of not knowing enough, or of not knowing the material sufficiently well to remember it all. Acute anxiety is aroused by what seems a request to be judged on only a part of what has been learned.

Yet if the relevant material were selected and discussed, the student's answer should develop fully satisfactory dimensions. The student is invited to display a lesser amount of factual knowledge, provided evidence of thought is added.

It is possible that this avoidance by the student of thinking out a new aspect is not irrational, but the result of learning from experience. Even good examination candidates considering a new aspect of a familiar subject discover that their knowledge is inadequate; items of related knowledge do not always present themselves. The candidate has either been content to accept words without close inquiry into meaning, or has learned the accepted formulie without considering all their implications.

Even where there is no discovery of ignorance, thought does not always operate smoothly ; although we have relevant points to make, they may not all occur to us, or arrange themselves in the appropriate pattern immediately. It could be argued that students should have thought so much about the subject beforehand that their thinking has become flexible and well integrated. It remains possible that the examiner calls for discussion of an unforeseen aspect. Thus the student's resistance, conscious or not, to following a new line of thought in examination circumstances (or elsewhere) might be well founded on past experience of unsuccessful effort. It is so 